\title{
Validation of the NEOS score in Chinese patients with anti-NMDAR encephalitis
}

Yujing Peng, MD, Feifei Dai, MD, Lei Liu, MD, Weiqi Chen, MD, Hongyi Yan, MD, Aihua Liu, MD, Xinghu Zhang, MD, PhD, Xiaohui Wang, MD, Junying He, MD, Yatong Li, MD, Chenxi Li, MD, Liuxi Chen, MD, Yan Zhao, MD, Lin Li, MD, Qiuying Ma, MD, and Jiawei Wang, MD, PhD

Neurol Neuroimmunol Neuroinflamm 2020;7:e860. doi:10.1212/NXI.0000000000000860

\section{Abstract}

\section{Objective}

The performance of anti-NMDAR Encephalitis One-Year Functional Status (NEOS) in predicting the 1-year functional status in Chinese patients with anti-NMDAR encephalitis is unknown.

\section{Methods}

We recruited patients with anti-NMDAR encephalitis from the Multicenter and Prospective Clinical Registry Study of Anti-NMDAR Encephalitis in Beijing Area. Patients were followed up for 1 year. We defined the poor functional status as a modified Rankin Scale score of more than 2 and good functional status as a modified Rankin Scale score of no more than 2 . We performed a receiver-operator characteristic analysis to assess the discriminatory power of the NEOS score in predicting the 1-year functional status by using the area under the curve (AUC). Calibration was assessed by Pearson correlation coefficient and Hosmer-Lemeshow tests.

\section{Results}

Among the 111 patients with anti-NMDAR encephalitis recruited from 364 potentially eligible participants, 87 (78.4\%) had good functional status at 1 year, whereas the remaining $24(21.6 \%)$ had poor functional status. The AUC of the NEOS score for 1-year poor functional status was 0.86 (95\% CI 0.78-0.93, $p<0.001$ ). The increased NEOS was associated with higher risk of 1 -year poor functional status in patients with anti-NMDAR encephalitis.

\section{Conclusions}

The NEOS score is considered a reliable predictor of the risk of 1 -year poor functional status in Chinese patients with anti-NMDAR encephalitis. This score could help to estimate the velocity of clinical improvement in advance.

\section{Clinicaltrial.gov identifier}

NCT02443350.

\section{Classification of evidence}

This study provides Class III evidence that in patients with anti-NMDAR encephalitis, the NEOS score predicts 1-year functional status.

\author{
Correspondence \\ Dr. Wang \\ wangjwcq@163.com
}

\section{MORE ONLINE}

$\rightarrow$ Class of Evidence

Criteria for rating

therapeutic and diagnostic

studies

NPub.org/coe

From the Department of Neurology, Beijing Tong Ren Hospital, Capital Medical University (Y.P., F.D., L. Liu, Y.L., C.L., L.C., Y.Z., L. Li, Q.M., J.W.); Medical Research Center, Beijing Tong Ren Hospital, Capital Medical University (Y.P., F.D., L. Liu, Y.L., C.L., L.C., Y.Z., L. Li, Q.M., J.W.); Department of Neurology, Beijing Tiantan Hospital, Capital Medical University (W.C., H.Y., X.Z.); Department of Neurology, Xuanwu Hospital, Capital Medical University (A.L.), Beijing; Beijing Children Hospital, Capital Medical University (X.W.); Department of Neurology, the Second Hospital of Hebei Medical University (J.H.), Shijiazhuang; China National Clinical Research Center for Neurological Diseases (W.C., H.Y.), Beijing; Center of Stroke, Beijing Institute for Brain Disorders (W.C., H.Y.); and Beijing Key Laboratory of Translational Medicine for Cerebrovascular Disease (W.C., H.Y.), China. 


\section{Glossary}

AUC $=$ area under the receiver operating characteristic curve; $\mathbf{I C U}=$ intensive care unit; $\mathbf{m R S}=$ modified Rankin Scale; NEOS = anti-NMDAR Encephalitis One-Year Functional Status; WBC = white blood cell.

Anti-NMDAR encephalitis is a rare, debilitating, and potentially treatable condition that is characterized by acute to subacute psychiatric and/or neurologic complaints. ${ }^{1}$ Early identification of patients with poor prognosis remains to be a major concern in clinical practice. ${ }^{2,3}$ Some predictive factors, such as delayed treatment, ${ }^{4-6}$ intensive care unit (ICU) admission, ${ }^{7-9}$ and abnormal CSF inflammation, ${ }^{3,10}$ might be considered useful in the early identification of patients with poor prognosis. The antiNMDAR Encephalitis One-Year Functional Status (NEOS) score, including not only the aforementioned factors, has been developed and assisted in predicting the risk of 1-year poor functional status, which in turn is useful in deciding whether early second-line immunotherapy or other novel salvage therapies should be offered to those patients with anti-NMDAR encephalitis. ${ }^{11}$ However, it has not been validated in Chinese population to date. This study aimed to validate the performance of the NEOS score in Chinese patients with anti-NMDAR encephalitis for predicting poor functional status at 1 year.

\section{Methods}

\section{Data sources}

The Multicenter and Prospective Clinical Registry Study of Anti-NMDAR Encephalitis in Beijing Area (Clinicaltrials. gov number: NCT02443350) was a multicenter clinically registered study with consecutive suspected patients with encephalitis conducted at 5 clinical centers in China. The inclusion criteria were as follows: patients (1) older than 6 months; (2) with at least one or more clinical features of the following: fever, epilepsy, focal neurologic deficiency symptoms, changes in CSF, changes in EEG, and radiographic abnormalities; (3) with confirmed anti-NMDAR encephalitis whose CSF or serum showing a characteristic pattern of reactivity in rat brain tissues and specific immunolabeling of HEK293 cells expressing GluN1 subunits of NMDAR ${ }^{12,13}$; and (4) screened at least once for systemic tumors.

\section{Study population}

We enrolled patients with anti-NMDAR encephalitis with the available information between July 15, 2014, and February 20, 2019. All participants signed written informed consent before study initiation. This study was approved by the ethics committee of each study center. A total of 364 patients were included, and 245 (67\%) among these were excluded because they were diagnosed with other diseases and 8 (7\%) patients were lost to follow up (figure 1).

\section{Figure 1 Trial profile}

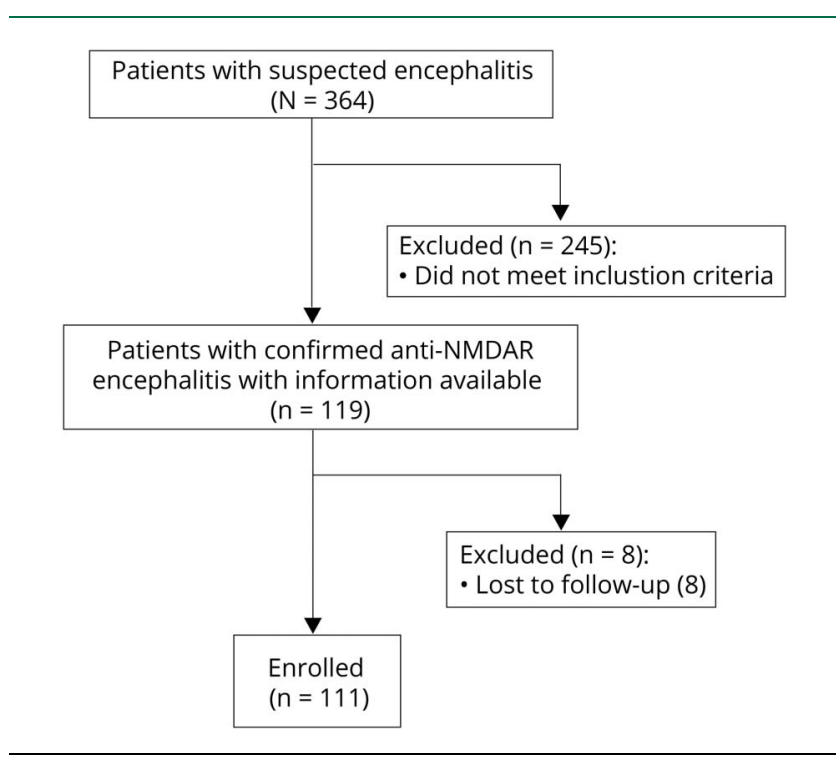

\section{Data collection and follow-up}

We collected detailed information of baseline demographics, time of symptom onset, clinical features, therapeutic regimen, and the 5 variables involved in the NEOS score (see below). The follow-up duration was at least 1 year, and the information of functional status (quantified using the modified Rankin Scale $[\mathrm{mRS}]$ ) was collected through face to face or telephone by neurologists who were not aware of this study. Poor functional status was defined as a mRS score of more than 2 (mRS score of 6 represents death), whereas good functional status was defined as a mRS score of no more than 2. We defined relapse of encephalitis as the new onset or worsening of symptoms occurring after at least 2 months of improvement or stabilization. ${ }^{4}$ Mortality occurs because of encephalitis or its associated complications. The outcomes discussed above were determined by at least 2 neurologists based on the clinical features. If there was any disagreement, we would resort to a third senior neurologist to reach a consensus decision. EEG was classified as abnormal when the presence of any of the following was recorded: electrographic seizures, rhythmic slowing, epileptic form discharges, extreme delta brush, ${ }^{14}$ focal or diffuse slowing, or abnormal state changes. Brain MRI scans were classified as abnormal if the images determined by both radiologists and neurologists were consistent or suggestive of encephalitis. ${ }^{7}$

\section{NEOS score}

The NEOS score ${ }^{11}$ was derived from the study conducted by Balu and his colleagues, in which 382 patients with confirmed anti-NMDAR encephalitis were recruited. A multivariable 
logistic regression model was constructed by entering variables of ICU admission, the absence of treatment for more than 4 weeks, improvement delay of more than 4 weeks after starting treatment, abnormal MRI, and CSF white blood cell (WBC) count of more than 20 cells $/ \mu \mathrm{L}$. Each variable was given 1 point, and the score ranges from 0 to 5 points. The NEOS score was strongly associated with the probability of poor functional status at 1 year.

\section{Statistical analysis}

The categorical variables were presented as frequencies (percentages). The baseline variables were analyzed by $\chi^{2}$ statistics or Fisher exact tests. OR with 95\% CI was used to measure the effect of the NEOS score. We tested the performance of the NEOS score by estimating its discrimination and calibration. The discriminatory power of the NEOS score was assessed by the area under the receiver operating characteristic curves (AUCs) and 95\% CI. An AUC of 1.0 indicated perfect prediction, and 0.5 indicated no better than random prediction. Calibration was assessed by using Pearson correlation coefficient and Hosmer-Lemeshow tests. The $\alpha$ level of significance was $p<0.05$ on both sides. All analyses were performed using SPSS (version 25; IBM Corp., Armonk, $\mathrm{NY}$ ) and SAS software version 9.3 (SAS Institute Inc., Cary, NC).

\section{Classification of evidence}

The primary aim was to explore whether the NEOS score was appropriate for Chinese patients with anti-NMDAR encephalitis to predict the poor functional status at 1 year. The classification of evidence assigned to these questions is Class III.

\section{Data availability}

All data are available to researchers on request for the purpose of reproducing the results or replicating the procedure by directly contacting the corresponding author.

\section{Results}

\section{Patient characteristics}

Of the 111 patients, 87 (78.4\%) had good functional status at 1 year, whereas the remaining $24(21.6 \%)$ had poor functional status. All the 24 patients with poor functional status at 1 year were followed up for 2 years after initial presentation. In this subset after follow-up for 2 years, 7 (29.2\%) were recovered to good functional status.

The baseline characteristics of patients are shown in table 1 . The patients with poor functional status were more likely to be younger, had central hypoventilation, had abnormal MRI, had CSF WBC counts of more than 20 cells $\mu \mathrm{L}$, had no treatment within 4 weeks of symptom onset, had treatment delay of $>4$ weeks, and had first-line immunotherapy (table 1 ).

\section{NEOS score and risk of poor functional status}

As shown in table 2, patients with higher NEOS scores have significantly higher rate of 1 -year poor functional status. The
AUC of the NEOS score was presented in figure 2. The NEOS score was shown to be a significant predictor of poor functional status (AUC 0.86, 95\% CI 0.78-0.93, $p<0.001$ ).

\section{Calibration ability of the NEOS score}

Calibration analysis of the NEOS score showed a moderate correlation between the predicted and observed probabilities of 1-year poor functional status, and the coefficient of $r$ was $0.53(p<0.001)$. The significance level of the HosmerLemeshow test for prediction of poor functional status was 0.35 (figure 3).

\section{Discussion}

Our study showed that the NEOS score well predicted the probability of 1-year poor functional status after initial symptom presentation in Chinese patients with anti-NMDAR encephalitis.

For patients with poor status, the slow and variable trajectory of recovery and step-by-step treatment meant delay in more effective treatment, imparting significant stress onto the family members of patients. ${ }^{15}$ Understanding the possible prognosis is essential in providing information to clinicians, patients, and families, as well as potentially influencing the future treatment strategies. The NEOS score can be easily calculated at bedside within 4 weeks of treatment initiation and capable of discriminating the differences in the probability of poor functional status at 1 year over a wide range of score value. To some extent, this might help clinicians to counsel patients and their families. Furthermore, to our knowledge, our study is the first prospective study to externally validate the NEOS score, except the original study.

This study showed several features that are not consistent with the original NEOS study. Patients with anti-NMDAR encephalitis in our study demonstrated a lower incidence in women, with tumors, central hypoventilation, and a better prognosis, and this is consistent with the results of previous studies in China. ${ }^{16-18}$ There was no sex difference, but a tendency to women was found. The prevalence of tumors was also lower in the Korean population than in the Western study populations. ${ }^{19}$ Experts have suggested that a race-specific factor, the human leucocyte antigen, or other genetic factors might play a significant role. ${ }^{20}$ It is unclear as to whether the discrepancy of central hypoventilation incidence occurs because of earlier diagnosis or if they showed location differences in the brainstem control of breathing or expression of NMDAR between different populations. The specific mechanism requires further exploration on brain imaging and animal model. In addition, more than half of the patients (57\%) were juveniles in our sample. An anti-NMDAR encephalitis study on children and adolescents has reported that the incidence of central hypoventilation in juveniles is lower, and the symptoms seemed to be less severe than that in adults. ${ }^{21}$ As a matter of fact, the main reasons for ICU admission in our 
Table 1 Characteristics of patients with anti-NMDA receptor encephalitis

\begin{tabular}{|c|c|c|c|}
\hline & Good status (N = 87), n (\%) & Poor status $(\mathrm{N}=24), \mathrm{n}(\%)$ & $p$ Value \\
\hline Age, y & & & 0.016 \\
\hline$<45$ & $82(94.3)$ & $18(75)$ & \\
\hline$\geq 45$ & $5(5.7)$ & $6(25)$ & \\
\hline Female & $48(55.2)$ & $15(62.5)$ & 0.52 \\
\hline Tumor & $4(4.6)$ & $0(0)$ & 0.29 \\
\hline Altered behavior & $72(82.8)$ & $22(91.7)$ & 0.45 \\
\hline Memory impairment & $37(42.5)$ & $15(62.5)$ & 0.08 \\
\hline Speech disorder & $53(60.9)$ & $15(62.5)$ & 0.89 \\
\hline Seizure & $72(82.8)$ & $18(75)$ & 0.57 \\
\hline Reduced consciousness & $42(48.3)$ & $8(36.4)$ & 0.32 \\
\hline Movement disorder & $60(69)$ & $19(79.2)$ & 0.33 \\
\hline Sleep disturbance & $51(58.6)$ & $15(62.5)$ & 0.73 \\
\hline Autonomic dysfunction & $27(31)$ & $11(45.8)$ & 0.18 \\
\hline Central hypoventilation & $0(0)$ & $7(29.2)$ & $<0.001$ \\
\hline Requires ICU admission & $26(29.9)$ & $9(37.5)$ & 0.48 \\
\hline Abnormal EEG & $60(70.6)$ & $19(79.2)$ & 0.41 \\
\hline Abnormal MRI & $36(41.4)$ & $20(83.3)$ & $<0.001$ \\
\hline CSF WBC count & & & 0.045 \\
\hline$\leq 20$ cells $/ \mu \mathrm{L}$ & $56(64.4)$ & $10(41.7)$ & \\
\hline$>20$ cells $/ \mu \mathrm{L}$ & $31(35.6)$ & $14(58.3)$ & \\
\hline Time to start of treatment after symptom onset & & & $<0.001$ \\
\hline$\leq 4 \mathbf{w k}$ & $71(81.6)$ & $8(33.3)$ & \\
\hline$>4$ wk & $16(18.4)$ & $16(66.7)$ & \\
\hline Time to initial improvement & & & $<0.001$ \\
\hline$\leq 4 \mathrm{wk}$ & $69(79.3)$ & $4(16.7)$ & \\
\hline$>4 \mathbf{w k}$ & $18(20.7)$ & $20(83.3)$ & \\
\hline Line of immunotherapy & & & 0.038 \\
\hline First & $66(75.9)$ & $13(54.2)$ & \\
\hline Second & $21(24.1)$ & $11(45.8)$ & \\
\hline
\end{tabular}

Abbreviations: ICU = intensive care unit; $\mathrm{WBC}=$ white blood cell.

cohort were coma, seizures, agitation/confusion, and acute respiratory failure in turn. Multiple studies reported better prognosis in the Chinese population, suggesting that the prognosis of anti-NMDAR encephalitis might be predominantly related to race and natural history of the disorder.

However, our study has some limitations. First, our study included only 5 major hospitals with more medical resources and experts than other hospitals in rural areas and included small sample size. Thus, selection bias can arise in the study. Studies with larger sample size are warranted to validate external validity of the NEOS score and to better identify the subgroup of patients with poor functional status. Second, the study included variations in treatment approaches. For pediatric patients, second-line immunotherapy might be limited because of security reasons when first-line therapies fail. Third, Western populations were not included, and so inter-racial differences cannot be excluded. Finally, our study lacked biomarkers that are connected with response to treatment, which might decrease the scores' ability to predict the ultimate clinical outcome. 
Table 2 NEOS score and risk of poor functional status

\begin{tabular}{lllll}
\hline $\begin{array}{l}\text { Outcome } \\
\text { Poor } \\
\text { status }\end{array}$ & $\begin{array}{l}\text { NEOS } \\
\text { score }\end{array}$ & $\mathrm{n} / \mathrm{N}$ & OR $(95 \% \mathrm{Cl})$ & $\begin{array}{l}\boldsymbol{p} \\
\text { Value }\end{array}$ \\
\hline & $0-1$ & $1 / 53(1.89)$ & Reference & - \\
\hline 2 & $3 / 21(14.29)$ & $8.67(0.85-88.70)$ & 0.069 \\
\hline 3 & $11 / 23$ & $\begin{array}{l}47.67 \\
(5.60-405.62)\end{array}$ & $<0.001$ \\
\hline $4-5$ & $(47.83)$ & $\begin{array}{l}69.33 \\
(7.35-653.91)\end{array}$ & $<0.001$ \\
\hline
\end{tabular}

Abbreviation: NEOS = anti-NMDAR Encephalitis One-Year Functional Status.

In conclusion, our study showed that the NEOS score was a reliable and accurate tool for physicians to predict the risk of poor functional status in Chinese patients with antiNMDAR encephalitis at 1 year. This score could be helpful to estimate the velocity of clinical improvement and might allow clinicians to stratify patients who could benefit from novel therapies in the future clinical trials.

\section{Acknowledgment}

The authors thank Yuesong Pan from Beijing Tiantan Hospital, Capital Medical University, Beijing, China, for providing statistics assistance, and Jiejie Li from Beijing Tiantan Hospital, Capital Medical University, Beijing, China, for revising the manuscript. In addition, they appreciated all the investigators and patients who participated in the registry.

Figure 2 Receiver operator characteristic curve for prediction of 1-year prognosis of the NEOS score

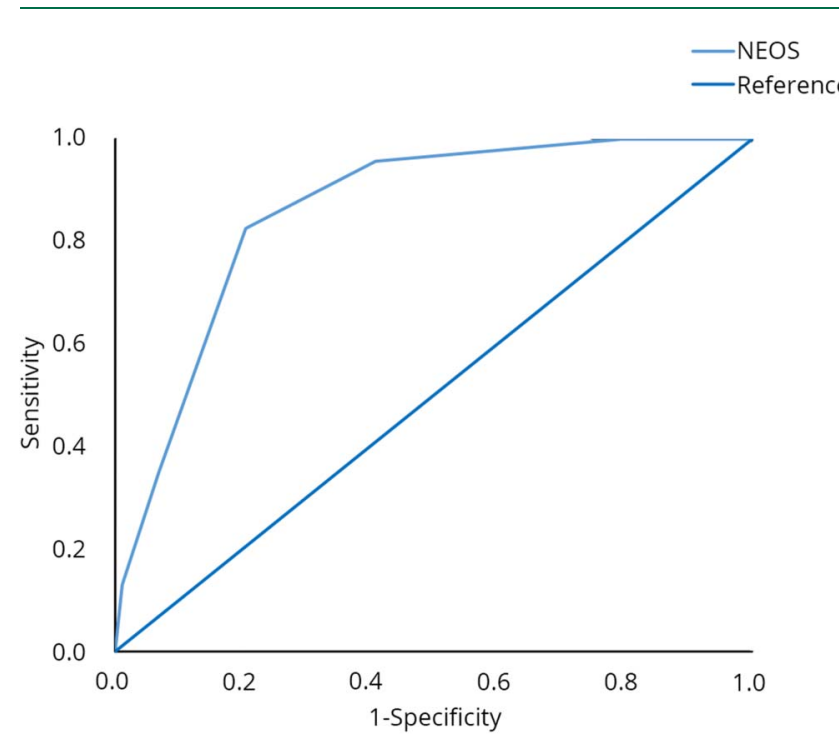

NEOS = anti-NMDAR Encephalitis One-Year Functional Status.
Figure 3 Calibration plot of the NEOS score for poor functional status

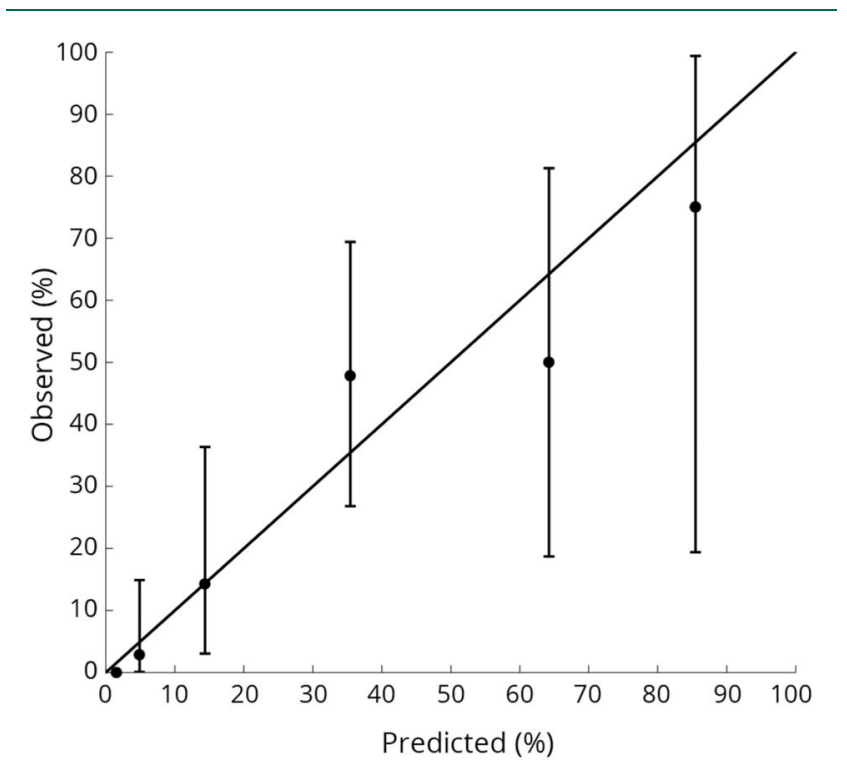

The vertical lines indicate $95 \% \mathrm{Cls}$ of predicted rates of clinical status. NEOS = anti-NMDAR Encephalitis One-Year Functional Status.

\section{Study funding}

Supported by grants from the following: National Natural Science Foundation of China (81771313, 81870950); Youth Program of National Natural Science Foundation of China (81301029); Beijing Municipal Natural Science Foundation (19G11041, 7182077); Beijing Hospitals Authority Youth Program (QML20150206); Key Research and Development Plan of the Ministry of Science and Technology of the People's Republic of China (2016YFC0904502); Beijing Science and Technology Project "Capital Characteristics" (Z171100001017039); Key Projects of Medical Development in Capital (2014-1-1101); Beijing Tongren Hospital, Capital Medical University, Key Medical Development Plan (TRYY-KYJJ-2017-054).

\section{Disclosure}

The authors have no conflicts interest to declare as regards this study. Go to Neurology.org/NN for full disclosures.

\section{Publication history}

Received by Neurology: Neuroimmunology \& Neuroinflammation March 30, 2020. Accepted in final form June 29, 2020.

\begin{tabular}{lll}
\multicolumn{2}{l}{ Appendix } & Authors \\
\hline Name & Location & Contribution \\
\hline $\begin{array}{l}\text { Yujing } \\
\text { Peng, MD }\end{array}$ & $\begin{array}{l}\text { Capital Medical } \\
\text { University, China }\end{array}$ & $\begin{array}{l}\text { Study concept and design, } \\
\text { acquisition of data, data } \\
\text { analysis and interpretation, } \\
\text { and manuscript drafting }\end{array}$ \\
$\begin{array}{l}\text { Feifei Dai, } \\
\text { MD }\end{array}$ & $\begin{array}{l}\text { Beijing Tong Ren } \\
\text { Hospital, China }\end{array}$ & $\begin{array}{l}\text { Acquisition of data and study } \\
\text { supervision or coordination }\end{array}$ \\
\hline
\end{tabular}


Appendix (continued)

\begin{tabular}{|c|c|c|}
\hline Name & Location & Contribution \\
\hline $\begin{array}{l}\text { Lei Liu, } \\
\text { MD }\end{array}$ & $\begin{array}{l}\text { Beijing Tong Ren } \\
\text { Hospital, China }\end{array}$ & $\begin{array}{l}\text { Acquisition of data and } \\
\text { manuscript revising }\end{array}$ \\
\hline $\begin{array}{l}\text { Weiqi } \\
\text { Chen, MD }\end{array}$ & $\begin{array}{l}\text { Beijing Tiantan Hospital, } \\
\text { China }\end{array}$ & Manuscript revising \\
\hline $\begin{array}{l}\text { Hongyi } \\
\text { Yan, MD }\end{array}$ & $\begin{array}{l}\text { Beijing Tiantan Hospital, } \\
\text { China }\end{array}$ & $\begin{array}{l}\text { Data analysis and } \\
\text { interpretation }\end{array}$ \\
\hline $\begin{array}{l}\text { Aihua Liu, } \\
\text { MD }\end{array}$ & Xuanwu Hospital, China & $\begin{array}{l}\text { Acquisition of data and study } \\
\text { supervision or coordination }\end{array}$ \\
\hline $\begin{array}{l}\text { Xinghu } \\
\text { Zhang, } \\
\text { MD, PhD }\end{array}$ & $\begin{array}{l}\text { Beijing Tiantan Hospital, } \\
\text { China }\end{array}$ & $\begin{array}{l}\text { Acquisition of data and study } \\
\text { supervision or coordination }\end{array}$ \\
\hline $\begin{array}{l}\text { Xiaohui } \\
\text { Wang, MD }\end{array}$ & $\begin{array}{l}\text { Beijing Children Hospital, } \\
\text { China }\end{array}$ & $\begin{array}{l}\text { Acquisition of data and study } \\
\text { supervision or coordination }\end{array}$ \\
\hline $\begin{array}{l}\text { Junying } \\
\text { He, MD }\end{array}$ & $\begin{array}{l}\text { The Second Hospital of } \\
\text { Hebei Medical } \\
\text { University, China }\end{array}$ & $\begin{array}{l}\text { Acquisition of data and study } \\
\text { supervision or coordination }\end{array}$ \\
\hline $\begin{array}{l}\text { Yatong Li, } \\
\text { MD }\end{array}$ & $\begin{array}{l}\text { Beijing Tong Ren } \\
\text { Hospital, China }\end{array}$ & Acquisition of data \\
\hline $\begin{array}{l}\text { Chenxi Li, } \\
\text { MD }\end{array}$ & $\begin{array}{l}\text { Beijing Tong Ren } \\
\text { Hospital, China }\end{array}$ & Acquisition of data \\
\hline $\begin{array}{l}\text { Liuxi } \\
\text { Chen, MD }\end{array}$ & $\begin{array}{l}\text { Beijing Tong Ren } \\
\text { Hospital, China }\end{array}$ & Acquisition of data \\
\hline $\begin{array}{l}\text { Yan Zhao, } \\
\text { MD }\end{array}$ & $\begin{array}{l}\text { Beijing Tong Ren } \\
\text { Hospital, China }\end{array}$ & Acquisition of data \\
\hline Lin Li, MD & $\begin{array}{l}\text { Beijing Tong Ren } \\
\text { Hospital, China }\end{array}$ & Acquisition of data \\
\hline $\begin{array}{l}\text { Qiuying } \\
\text { Ma, MD }\end{array}$ & $\begin{array}{l}\text { Beijing Tong Ren } \\
\text { Hospital, China }\end{array}$ & Acquisition of data \\
\hline $\begin{array}{l}\text { Jiawei } \\
\text { Wang, MD, } \\
\text { PhD }\end{array}$ & $\begin{array}{l}\text { Beijing Tong Ren } \\
\text { Hospital, China }\end{array}$ & $\begin{array}{l}\text { Study concept and design, data } \\
\text { analysis and interpretation, } \\
\text { obtaining funding, and study } \\
\text { supervision or coordination }\end{array}$ \\
\hline
\end{tabular}

\section{References}

1. Dalmau J, Graus F. Antibody-mediated encephalitis. N Eng J Med 2018;378:840-851.

2. Dalmau J, Gleichman AJ, Hughes EG, et al. Anti-NMDA-receptor encephalitis: case series and analysis of the effects of antibodies. Lancet Neurol 2008;7:1091-1098.

3. Broadley J, Seneviratne U, Beech P, et al. Prognosticating autoimmune encephalitis: a systematic review. J Autoimmun 2019;96:24-34.

4. Titulaer MJ, McCracken L, Gabilondo I, et al. Treatment and prognostic factors for long-term outcome in patients with anti-NMDA receptor encephalitis: an observational cohort study. Lancet Neurol 2013;12:157-165.

5. Titulaer MJ, McCracken L, Gabilondo I, et al. Late-onset anti-NMDA receptor encephalitis. Neurology 2013;81:1058-1063.

6. Irani SR, Stagg CJ, Schott JM, et al. Faciobrachial dystonic seizures: the influence of immunotherapy on seizure control and prevention of cognitive impairment in a broadening phenotype. Brain 2013;136:3151-3162.

7. Graus F, Titulaer MJ, Balu R, et al. A clinical approach to diagnosis of autoimmune encephalitis. Lancet Neurol 2016;15:391-404.

8. Jaquet $\mathrm{P}$, de Montmollin E, Dupuis C, et al. Functional outcomes in adult patients with herpes simplex encephalitis admitted to the ICU: a multicenter cohort study. Intensive Care Med 2019;45:1103-1111.

9. de Montmollin E, Demeret S, Brulé N, et al. Anti-N-methyl-d-aspartate receptor encephalitis in adult patients requiring intensive care. Am J Respir Crit Care Med 2017;195:491-499.

10. Pillai SC, Hacohen Y, Tantsis E, et al. Infectious and autoantibody-associated encephalitis: clinical features and long-term outcome. Pediatrics 2015;135:e974-e984.

11. Balu R, McCracken L, Lancaster E, Graus F, Dalmau J, Titulaer MJ. A score that predicts 1-year functional status in patients with anti-NMDA receptor encephalitis. Neurology 2019;92:e244-e252.

12. Dalmau J, Lancaster E, Martinez-Hernandez E, Rosenfeld MR, Balice-Gordon R. Clinical experience and laboratory investigations in patients with anti-NMDAR encephalitis. Lancet Neurol 2011;10:63-74.

13. Li L, Sun L, Du R, et al. Application of the 2016 diagnostic approach for autoimmune encephalitis from Lancet Neurology to Chinese patients. BMC Neurol 2017;17:195.

14. Schmitt SE, Pargeon K, Frechette ES, Hirsch LJ, Dalmau J, Friedman D. Extreme delta brush: a unique EEG pattern in adults with anti-NMDA receptor encephalitis. Neurology 2012;79:1094-1100.

15. Vora NM, Holman RC, Mehal JM, Steiner CA, Blanton J, Sejvar J. Burden of encephalitisassociated hospitalizations in the United States, 1998-2010. Neurology 2014;82:443-451.

16. Wang W, Li JM, Hu FY, et al. Anti-NMDA receptor encephalitis: clinical characteristics, predictors of outcome and the knowledge gap in southwest China. Eur J Neurol 2016;23:621-629.

17. Wang Y, Zhang W, Yin J, et al. Anti-N-methyl-d-aspartate receptor encephalitis in children of Central South China: clinical features, treatment, influencing factors, and outcomes. J Neuroimmunol 2017;312:59-65.

18. Zhang Y, Liu G, Jiang M, Chen W, He Y, Su Y. Clinical characteristics and prognosis of severe anti-N-methyl-D-aspartate receptor encephalitis patients. Neurocrit Care 2018;29:264-272.

19. Lim JA, Lee ST, Jung KH, et al. Anti-N-methyl-d-aspartate receptor encephalitis in Korea: clinical features, treatment, and outcome. J Clin Neurol 2014;10:157-161.

20. Irani SR, Bera K, Waters $\mathrm{P}$, et al. $\mathrm{N}$-methyl-D-aspartate antibody encephalitis: temporal progression of clinical and paraclinical observations in a predominantly nonparaneoplastic disorder of both sexes. Brain 2010;133:1655-1667.

21. Florance NR, Davis RL, Lam C, et al. Anti-N-methyl-D-aspartate receptor (NMDAR) encephalitis in children and adolescents. Ann Neurol 2009;66:11-18. 


\title{
Neurology ${ }^{\oplus}$ \\ Neuroimmunology \& Neuroinflammation
}

\author{
Validation of the NEOS score in Chinese patients with anti-NMDAR encephalitis \\ Yujing Peng, Feifei Dai, Lei Liu, et al. \\ Neurol Neuroimmunol Neuroinflamm 2020;7; \\ DOI 10.1212/NXI.0000000000000860
}

This information is current as of August 5, 2020

Neurol Neuroimmunol Neuroinflamm is an official journal of the American Academy of Neurology.

Published since April 2014, it is an open-access, online-only, continuous publication journal. Copyright

Copyright (C) 2020 The Author(s). Published by Wolters Kluwer Health, Inc. on behalf of the American

Academy of Neurology.. All rights reserved. Online ISSN: 2332-7812.

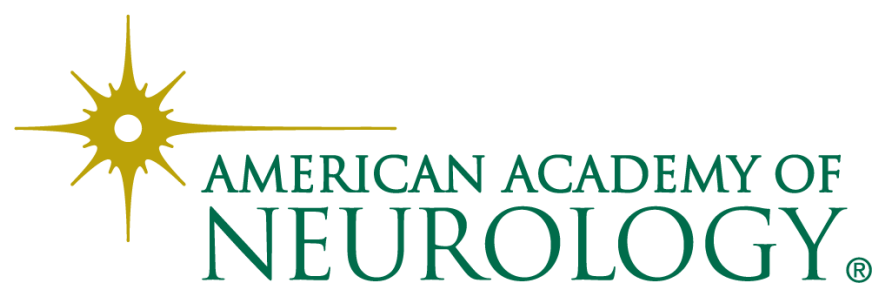




\section{Updated Information \& Services}

References

Citations

Subspecialty Collections

Permissions \& Licensing

Reprints including high resolution figures, can be found at: http://nn.neurology.org/content/7/5/e860.full.html

This article cites 21 articles, 0 of which you can access for free at: http://nn.neurology.org/content/7/5/e860.full.html\#\#ref-list-1

This article has been cited by 3 HighWire-hosted articles: http://nn.neurology.org/content/7/5/e860.full.html\#\#otherarticles

This article, along with others on similar topics, appears in the following collection(s):

Autoimmune diseases

http://nn.neurology.org//cgi/collection/autoimmune_diseases Class III http://nn.neurology.org//cgi/collection/class_iii

Clinical trials Observational study (Cohort, Case control) http://nn.neurology.org//cgi/collection/clinical_trials_observational_stu dy_cohort_case_control

Encephalitis

http://nn.neurology.org//cgi/collection/encephalitis

Prognosis

http://nn.neurology.org//cgi/collection/prognosis

Information about reproducing this article in parts (figures,tables) or in its entirety can be found online at:

http://nn.neurology.org/misc/about.xhtml\#permissions

Information about ordering reprints can be found online: http://nn.neurology.org/misc/addir.xhtml\#reprintsus

Neurol Neuroimmunol Neuroinflamm is an official journal of the American Academy of Neurology.

Published since April 2014, it is an open-access, online-only, continuous publication journal. Copyright

Copyright $\odot 2020$ The Author(s). Published by Wolters Kluwer Health, Inc. on behalf of the American Academy of Neurology.. All rights reserved. Online ISSN: 2332-7812.

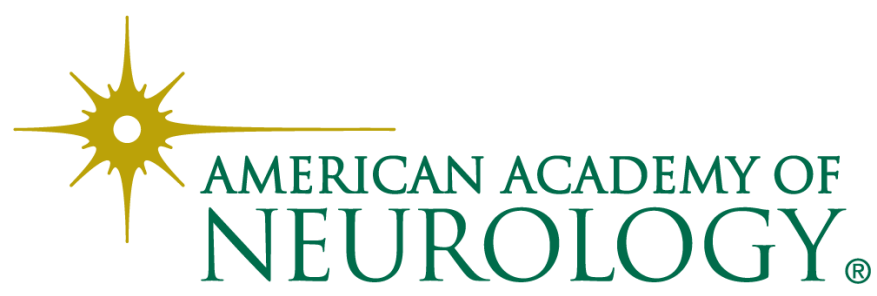

